\title{
ВИКОРИСТАННЯ ЗИГЗАГОПОДІБНОГО ДОСТУПУ ПРИ МАСТЕКТОМІї
}

\author{
В. В. Бойко, О. В. Овчаренко, В. В. Макаров, А. Ю. Бодрова \\ Харківський національний медичний університет \\ APPLICATION OF A ZIGZAG-LIKE ACCESS IN MASTECTOMY
}

\author{
V. V. Boyko, O. V. Ovcharenko, V. V. Makarov, A. Yu. Bodrova \\ Kharkiv National Medical University
}

\section{Рефрерат}

Наведені результати лікування 74 хворих з приводу раку грудної залози (РГЗ), у яких здійснена однобічна радикальна мастектомія. У 38 пацієнток (група порівняння) втручання виконували за класичною методикою, у 36 (основна група)- застосований зигзагоподібний доступ. У пацієнток основної групи перебіг післяопераційного періоду більш сприятливий, ніж в групі порівняння: останній дренаж видаляли на 5,9 доби раніше, тривалість застосування парентеральної знеболювальної терапії на 5,3 доби менша, частота часткової неспроможності швів на 10,4\%, виникнення сероми - на 7,6\% менша; нагноєння операційної рани не було.

Ключові слова: рак грудної залози; хірургічне лікування; зигзагоподібний доступ; лімфорея.

Abstract

Results of treatment of 74 patients, suffering mammary gland cancer, after a one-side radical mastectomy were adduced. In 38 womenpatients (the comparison group) the intervention was performed in accordance to classic procedure, in 36 (the main group)- a zigzaglike access was applied. In women-patients of the main group the postoperative period course is more favorable, than in the comparison group: the last drain was removed by 5.9 days earlier, duration of the parenteral analgetic therapy - by 5.3 days esser, the partial insufficiency of sutures -by $10.4 \%$ lesser, and the seroma occurrence - by $7.6 \%$ lesser; the operative wound suppuration was absent.

Keywords: mammary gland cancer; surgical treatment; zigzag-like operative access; lymphorrhea.

Найбільш частим раннім ускладненням хірургічного лікування РГЗ є лімфорея. Причинами іiі, незалежно від обсягу хірургічного втручання на грудній залозі, є пересічення лімфатичних колекторів, видалення пахвових, підключичних, підлопаткових лімфатичних вузлів, неможливість лігування всіх пересічених лімфатичних судин через відсутність візуалізації більшості з них. Внаслідок недостатнього прилягання клаптів шкіри до грудної стінки і пересічення значної кількості лімфатичних судин в рані накопичується серозна й геморагічна рідина. Найчастіше серома локалізується в пахвовій ямці, дещо рідше - в ділянці відсепарованого клаптя шкіри [1 - 3]. За даними ультразвукового дослідження, рідину в пахвовій ділянці виявляли у 92\% пацієнтів, у яких здійснено дисекцію регіонарних лімфатичних вузлів під час виконання органозберігальних втручань [4].

Найбільш часто для лікування лімфореї і сером здійснюють пункцію, дренування, введення склерозуючих речовин в «мертву» порожнину, щільне бинтування [5 - 7].

3 метою профілактики лімфореї використовують різні методики міопластики, найбільш пошире- ними 3 них є міопластика 3 поворотом малого грудного м'яза, використанням ділянок найширшого м'яза спини і переднього зубчастого м'яза. За даними літератури, відзначають рубцеву деформацію переміщеної ділянки м'яза при міопластиці [7, 8]. Особливо це небезпечно в проекції пахвової вени, що може спричинити порушення в ній кровотоку 3 подальшим виникненням тромбозу. Міопластика з використанням малого грудного м'яза дозволяє усунути «вільну» порожнину тільки в проекції пахвової ямки. Ділянки найширшого м'яза спини і зубчастого м'яза використовують за наявності «вільної» порожнини в нижній латеральній частині операційної рани. Для міопластики «вільної» порожнини використовують кілька м'язів, що $є$ досить травматичним, супроводжується виникненням вираженого больового синдрому після операції [3, 7].

Додаткове висічення країв рани при використанні стандартного доступу для усунення «вільної» порожнини зумовлює додатковий натяг мобілізованої ділянки шкіри на значному протязі, деформацію післяопераційного рубця, неспроможність шва шкіри $[3,4]$.

\section{МАТЕРІАЛИ I МЕТОДИ ДОСЛІДЖЕННЯ}

Представлені результати комплексного лікування 74 хворих з приводу РГЗ за період з 2006 по 2016 р. у відділенні торакоабдомінальної хірургії Інституту загальної та невідкладної хірургії імені В. Т. Зайцева НАМН України та мамологічному відділені Харківського обласного клінічного онкологічного центру.

Проаналізовані дані історій хвороби 38 пацієнток, яким у 2006 2011 рр. були виконані радикальні оперативні втручання з приводу РГЗ за класичною методикою, без застосування будь-яких додаткових iнтраопераційних методів профілактики лімфореї. Операцію завершували встановленням вакуум-дренажів. Ці хворі склали групу порівняння.

Вивчені результати лікування 36 пацієнток у 2012 - 2016 рр., при виконанні радикальної мастектомії використовували запропонований зигзагоподібний доступ (основна група).

В усіх хворих виконана однобічна радикальна мастектомія за мадденом.

У хворих групи порівняння під час виконання мастектомії застосований стандартний доступ, двома 
напівмісяцевими розрізами розсікали тканини, мобілізували грудну залозу. Цей доступ дозволяє виконати радикальну операцію з лімфодисекцією.

Проте, при застосуванні такого доступу в пахвовій ділянці утворюються «вільні» порожнини, що зумовлює тривалу лімфорею, виникнення сером, нагноєння операційної рани. Для попередження виникнення таких «вільних» порожнин застосовують різні методики: накладання внутрішніх швів, виконання різних видів міопластики 3 метою заповнення порожнин, додаткове висічення країв рани.

Накладання внутрішніх швів дозволяє зменшити об'єм «вільної» порожнини, проте, повністю не усуває іiі. Можливе виникнення сероми та затікання рідини між накладеними швами. При застосуванні цієї методики у пацієнток відзначали виражений больовий синдром, зменшення рухливості грудної стінки в ділянці оперативного втручання, деформацію тканин грудної стінки і післяопераційного рубця при накладанні внутрішніх швів [2, 7].

Нами запропонований зигзагоподібний доступ для виконання радикальної мастектомії (рис. 1).

Операційний доступ починаємо від задньої пахвової лінії, виконуемо розрізи шкіри в медіальному напрямку донизу АВ і АС, причому кут САВ має бути $30-45^{\circ}$. Навколо грудної залози виконуємо розрізи в медіальному напрямку і дещо вгору BF i СЕ. Залишаючи 1/3 до медіального краю грудної залози, виконуємо розрізи FD та ED. Важливим моментом $€$ дотримання довжини розрізів співвідносно з розмірами грудної залози. Розрізи AB, AC, FD, ED приблизно однакові, становлять 25\% довжини загального розрізу; розрізи ВF і $\mathrm{CE}$ - близько 50\% довжини розрізу. В подальшому виконують етапи стандартної мастектомії з мобілізацією тканин грудної залози в напрямку від пригруднинної до пахвової ділянки.

Після виконання всіх етапів радикальної мастектомії і дренування зашивають операційну рану.

При використанні запропонованого доступу зашивання операційної рани починають 3 накладання вузлових швів ниткою Vicryl
№ 3 між точками B і C, потім- F і E. Накладання цих швів дає уявлення хірургу про особливості зіставлення країв рани та наявність «вільних» порожнин. Як правило, накладання шва ВС забезпечує хороше зіставлення країв рани, уникнення «вільних» порожнин в пахвовій ділянці.

При утворенні «вільної» порожнини іiі усувають шляхом видалення надлишків шкіри і підшкірного прошарку в проекції розрізів АВ і АC. Це дозволяє усунути «вільні» порожнини й уникнути деформації післяопераційного рубця. Далі зашивають підшкірний прошарок і шкіру за стандартними методиками в напрямку від точки А до точки D. За наявності надлишку шкіри і підшкірного прошарку їх висікали в проекції розрізів FD та ED. Деформацію післяопераційного шва не спостерігали.

Застосування зигзагоподібного доступу дозволяє уникати утворення залишкових порожнин підшкірного прошарку завдяки наявності надлишку тканини в проекції зони операції.

При зашиванні шкіри перевагу віддавали внутрішньошкірному шву, використовували нитку Prolene № 3. Шви знімали на 10 - 12-ту добу (рис. 2).

Після радикальної мастектомії за Мадденом з застосуванням зигзагоподібного доступу досягнуте максимально фізіологічне зіставлення тканин операційної рани, що сприяє більш швидкій реабілітації та більш швидкому відновленню пацієнток після операції. Слід зазначити, що в порівнянні з стандартним доступом, за якого відбувається натяг вздовж усієї лінії швів, зигзагоподібний доступ забезпечує розподіл натягу між швами, оскільки максимальний натяг тканин відзначають при накладанні вузлів BC та ЕF. Це дозволяе зменшити обмеження обсягу рухів в плечовому суглобі внаслідок зменшення сили натягу шкіри та підшкірного прошарку в порівнянні з такою за стандартних методик зашивання операційної рани.

Рух в плечовому суглобі на боці мастектомії за Мадденом з застосуванням зигзагоподібного доступу не обмежений.

Статистична обробка результатів проведена за допомогою персональ-

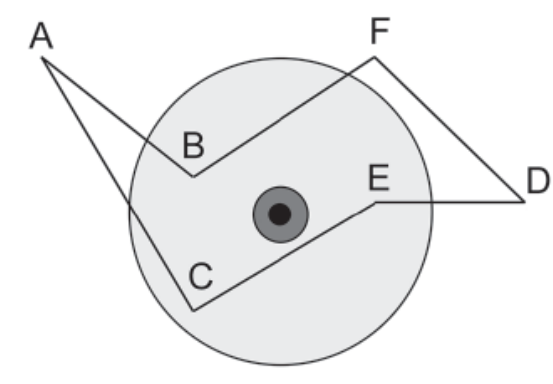

Рис. 1.

Схема зигзагоподібного доступу при радикальній мастектомії.

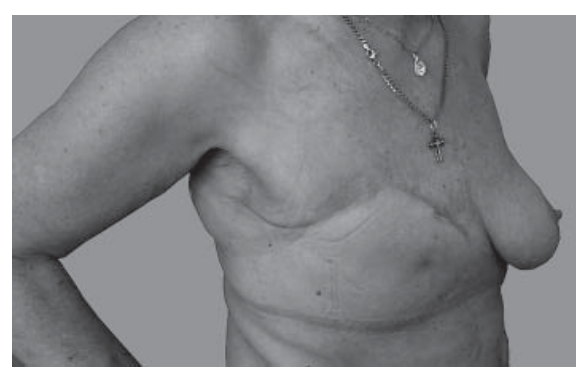

Рис. 2.

Пацієнтка Т., 72 років, через 1 міс після правобічної радикальної мастектомії за Мадденом з застосуванням зигзагоподібного доступу.

ного комп'ютера PC-AT IBM 586 з використанням методу варіаційної статистики, кореляційного аналізу. Використовували модифікацію пакета програм Statistica 5.0, Stsgrf, Biostat [9].

\section{РЕЗУЛЬТАТИ \\ ТА ÏХ ОБГОВОРЕННЯ}

У 3 (8,3\%) пацієнток основної групи здійснене додаткове висічення шкіри і підшкірного прошарку в проекції розрізів у відрізках АВ та AC 3 метою запобігання утворення «вільних» порожнин та забезпечення більш щільного прилягання мобілізованих клаптів шкіри.

У 2 (5,5\%) пацієнток виконане додаткове висічення шкіри і підшкірного прошарку в проекції розрізів у відрізках ED та FD з метою запобігання деформації післяопераційного рубця.

Клінічними критеріями ефективності хірургічного лікування з приводу РГЗ після операції вважали: тривалість та об'єм лімфореї, утворення сером, неспроможність швів, нагноєння операційної рани, вираженість больового синдрому, відновлення функції верхньої кінцівки на боці оперативного втручання. 
В усіх хворих інтраопераційно встановлені подвійні вакуумні дренажі, що дозволяло, крім евакуації рідини $з$ операційної рани, відстежувати добовий об'єм лімфореї після мастектомії. Вакуумні дренажі встановлювали в пригруднинній та пахвовій ділянках.

Дренаж видаляли при добовому об'ємі лімфореї у вакуумній «гармошці» 40 мл на добу і менше.

В усіх хворих на 4 - 5-ту добу першим видаляли пригруднинний дренаж, розташований вздовж рани. Дренаж з пахвової ділянки у хворих групи порівняння видаляли з 9-ї по 16-ту добу, залежно від добового об'єму лімфореї, у хворих основної групи- з 6-ї по 10-ту добу, що свідчило про ефективність запропонованих додаткових лікувальних заходів.

В ранньому післяопераційному періоді в усіх хворих відзначали продуктивну лімфорею та виражений больовий синдром.

У хворих групи порівняння мінімальна тривалість продуктивної лімфореї 9 діб, максимальна- 16 діб; у пацієнток основної групи- відповідно 6 і 10 діб.

Таким чином, застосування комплексу запропонованих лікувальних засобів в основній групі дозволило зменшити мінімальну тривалість продуктивної лімфореї на 3 доби, максимальної- на 6 діб, що свідчило про ефективність засобів інтрао- пераційної та післяопераційної профілактики лімфореї. Останній дренаж у хворих основної групи видаляли у середньому через 7,9 доби, в групі порівняння- через 13,06 доби. Зменшення цього показника в основній групі на 5,96 доби також відображає значно сприятливіший перебіг післяопераційного періоду.

Вираженість больового синдрому оцінювали за тривалістю проведення парентеральної знеболювальної терапії. В основній групі вона становила у середньому 8,9 доби, в групі порівняння- 14,2 доби. Зменшення цього показника в основній групі на 5,3 доби також свідчило про сприятливіший перебіг післяопераційного періоду.

Часткова неспроможність швів операційної рани відзначена в 1 (2,7\%) пацієнтки основної групи. У хворої діагностовані ожиріння III ступеня та цукровий діабет II типу. Довжина дефекту до 5 см, рана загоїлася вторинним натягом при використанні консервативних засобів.

В групі порівняння часткова неспроможність швів операційної рани виникла у 5 (13,1\%) пацієнток, довжина дефекту від 3,5 до 8,3 см. У 2 (5,2\%) пацієнток це ускладнення виникло на тлі цукрового діабету II типу та ожиріння II - III ступеня, у 3 (7,9\%) - зумовлене підвищеною силою натягу тканин в зоні лінії швів. В 1 (2,6\%) пацієнтки дефект загоївся вторинним натягом при ви- користанні консервативних засобів, у 4 (10,5\%) - здійснене оперативне втручання- висічення країв рани та накладання вторинних швів.

В основній групі нагноєння операційної рани не було, в групі порівняння це ускладнення виникло у 3 (7,8\%) пацієнток. Проведене розсічення та дренування запальної порожнини.

У пацієнток обох груп у строки від 3-го до 5-го тижня після операції спостерігали утворення сером в 3оні хірургічного втручання: у 2 (5,5\%) - основної групи, у 5 (13,1\%) - групи порівняння. Об'єм сероми в основній групі від 10 до 30 мл, застосований пункційний спосіб усунення ускладнення під ультразвуковою навігацією.

У пацієнток групи порівняння об'єм сероми від 10 до 150 мл. У 2 (5,2\%) пацієнток ускладнення усунуте пункційними методами, у 3 (7,9\%) - шляхом дренування сероми. В обох групах всі пацієнтки живі.

Таким чином, у пацієнток основної групи вдалося зменшити тривалість дренування на 5,9 доби, застосування парентеральної знеболювальної терапіі - на 5,3 доби, частоту часткової неспроможності швів операційної рани - на 10,4\%, утворення сером - на 7,6\%, уникнути нагноєння операційної рани. Це забезпечило значно сприятливіший перебіг післяопераційного періоду у хворих основної групи.

\section{REFERENCES}

1. Nakaz MOZ Ukrainy vid 30.06.2015 № 396 «Unifikovanyi klinichnyi protokol pervynnoi, vtorynnoi (spetsializovanoi), tretynnoi (vysokospetsializovanoi) medychnoi dopomohy «Rak molochnoi zalozy»». [In Ukrainian].

2. Malygin SE, Malygin EN, Peterson SB, i dr. Sovremennye aspekty khirurgicheskogo lecheniya raka molochnoy zhelezy. Vestnik novykh meditsinskikh tekhnologiy. 2008;(2):167-70. [In Russian].

3. Jangjoo A, Mehrabi BM, Aliakbarian M. Seroma formation after breast cancer surgery: incidence and risk factors. Tehran University Medical Journal. 2009;(5):368-73.

4. Chissov VI, Dar'yalova SL. Onkologiya: klinicheskie rekomendatsii. Moskva: GEOTAR-Media; 2009. 928 s. [In Russian].

5. Druzhkov OB, Druzhkov BK, Gataullin IG, Druzhkov MO. Optimizatsiya rezektsionnykh metodov khirurgicheskogo komponenta v kompleksnom lechenii raka molochnoy zhelezy. Meditsinskiy almanakh. 2010;(3):59-62. [In Russian].
6. Ivanov IV, Semiglazov VF, Krivorotko PV, Seleznev IK. Sovremennye aspekty vakuumnogo drenirovaniya ran posle operatsiy na molochnoy zheleze. Annaly khirurgii. 2006;(1):34-6. [In Russian].

7. Ozaslan S, Bora KB, Dogan L, et al. Effect of mechanical closure of dead space on seroma formation in modified radical mastectomy. Turkish Journal of Medical Sciences. 2010;(5):751-5.

8. Ismagilov AKh, Khasanov RSh, Shakirova GI. Mioplastika pri radikalnoy mastektomii kak metod profilaktiki dlitelnoy limforei. Sibirskiy onkologicheskiy zhurnal. 2008;2:51-2. [In Russian].

9. Lapach SN, Chubenko AV, Babich PN. Statisticheskie metody v mediko-biologicheskikh issledovaniyakh $\mathrm{s}$ ispolzovaniem Exel. Kyiv: Morion; 2001. 408 s. [In Russian]. 